\title{
TEACHER SOLUTION TO SOLVE THE PROBLEM IN IMPLEMENTING THE ACTIVITIES USED IN TEACHING SPEAKING ENGLISH IN ISLAMIC BOARDING SCHOOL DARUSSALAM GONTOR
}

\author{
Bakhtiar Mahmud \\ bakhtiarmsh@gmail.com \\ Law Faculty, Muria Kudus University
}

\begin{abstract}
Pesantren are Islamic boarding schools in Indonesia. Pondok Modern Darussalam Gontor s one of Indonesia's many Islamic boarding schools, or pesantren with its boarding school system, well-known for its success in bringing-up its students to have basic communicative ability in two foreign languages, Arabic and English. This term research is conducted in Darussalam gontor boarding school the objective of journal are to investigate 1) the teacher perception about teaching speaking; 2) the activities and implementation of activities in teaching speaking ; 3) the problems faced by the teachers in implementing the activities used in teaching in speaking in Darussalam Gontor; 4) teacher solution to solve the problem in implementing the actived used in teaching speaking. In Gontor, students have to speak in foreign language (English) in certain days. If they do not do that, they will be punished. In the past, the punishment was thigh caned, but at present it is the shave bald head. Since teaching speaking as foreign language is not easy, it is challenge for both the teacher and student. There are considerations that should be done such as providing language exposure, incorporating with different task and kinds of interactive activities outside the classroom, creating the language environment, providing language rules, rewards, sanctions and demand. Keywords: teaching speaking, teacher perception, boarding school
\end{abstract}

\section{INTRODUCTION}

The term pondok is of Arabic word fundûq that means dormitory or a place for stay and in this regard dormitory for students. The term pesantren is derived from the term santri (student), which is given prefix "pe" and suffix "an" and become pe-santri-an or pesantren (Castles, 2007) and hence it denotes the place where students (santri) stay at dormitory (pondok) for the purpose of education.Pondok Modern, located in a village called Gontor Indonesia, is an Islamic educational institution of which effort in teaching foreign languages-Arabic and English-is relatively great. As its main objective is to produce "cadres" for the leaders of Muslim community in Indonesia . Pondok Modern with its "unique" system (Castles, 2007) of teaching excels in making its students capable of producing active and acceptable target language utterances.

In stating the problem of the study, the writer formulates it into questions as follows:

1. How the teacher perception about teaching speaking?

2. How the activities and implementation of activities in teaching speaking?

3. How the problems faced by the teachers in implementing the activities used in teaching in speaking in Darussalam Gontor? 
4. How teacher solution to solve the problem in implementing the actived used in teaching speaking?

\section{LITERATURE REVIEW}

The study focuses on the discussion about the strategy of applying English as a daily language and also the problem faced in applying English as a daily language. So, the chapter consists of the following sections: the principles of language, learning strategy and teaching strategy, and strategy development. As is defined by Hornby, system is "a group of things or parts working together in a regular relation (Hornby: 1974: 877). The system of language teaching, then, consists of various activities each of which is complementarily related. Those language activities are integrated with the students' life system, as if they were parts of their life. There is no doubt, anyhow, that the frequency of being involved in the target language activities seems to be fairly effective in the formation of language habit.

Among the virtues of the mentioned teaching techniques, on the other hand, is that because students feel they can express themselves using foreign language, they become proud of themselves and motivated to improve their achievements. Smith, in favor of this, assert that "nothing fosters high motivation and positive attitude as does success (Smith: 1975). Because students feel capable of manipulating the language for the purpose of communication, they have enthusiasm to know further of the language, as they feel its usefulness instead of its uselessness. When students "could see the connection between what goes on in the foreign language class and the practical demands of his existence (Smith: 1975), they would have positive attitude towards the language.In this part, the writer divided into two parts, they are spoken and written language and language acquisition.

\section{Spoken and written language}

Fundamental distinction has to be made between speech and writing as aspects of language. This view is based on an appreciation of the nature and possible range of grammatical differences deriving from the respective conditions for the production and reception of language. There are some main features of speech, they are:

a. Speech as conversation implies a speaker - listener situation, with alternating roles. Features involved, therefore, are the physical situation and the presence of an observed listener.

b. Normal (informal) conversation requires the spontaneous application of language habits.

c. The signaling devices available to the speaker, apart from word and sentence structure, are gesture, stress and intonation.

d. The physical situation and the prompting of question permit and evoke laconic utterances

e. The speaker is prone to anomalies of usage which are either peculiar to speech or more characteristic of that medium.

\section{Language Acquisition}

If we consider the child's acquisition of language between the ages of about twelve months of five years, the first thing we might obverse is quantity of language involved is enormous.

\section{Learning Strategy And Teaching Strategy}

To make the discussion about learning and teaching strategy more clearly, so in this part, the writer divided into two points 


\section{Language learning strategy}

Learner strategies include any sets of operations, steps, plans, routines used by the learner to facilitate the obtaining, storage, retrieval and use information. That is what the learners do to learn and do to regulate their learning. Aaron Carton in his study noted that learners vary in their propensity to make inferences and in their ability to make valid, rational, and reasonable inferences.

\section{Communication strategies}

From the point of view of the learning process, communication strategies are very important because they allow the learner to remain in the conversation by continual exposure to natural conversation.

\section{Social strategies}

Social strategies are those activities learners engage in which afford them opportunities to be exposed to and practice their knowledge. In themselves they do not contribute to learning since they merely put the student in an environment where practice is possible.

Wong-Fillmore identified two social strategies: join a group and act as if you understand what is going on, even if you don't, and count on your friends for help. Although these strategies provide exposure to the target language, they contribute only indirectly to learning since they don't lead directly to the obtaining, storing, retrieving and using of language.

\section{METHOD}

This study is descriptive in the sense that it merely attempts to make an objective description of the existent condition. It was not carried out by manipulating the facts or giving special treatment towards the variables under study in order to obtain the expected results. Any prevailing characteristics which existed and were observed belonging to the research subject, in time of study, are described in details. In so far as the study was executed in a certain time, any changes taking place in the subject's condition before or after the execution of the study was not taken into consideration. Its design is, then, that of a case study.

The sources of the data refer to the location from which and the subjects from whom the data were collected. The location of the study was the physical and situational environments of Pondok Modern campus located at Gontor village in Ponorogo, East Java, Indonesia. The subjects were some teaching staff, authority holders, and students at the location being mentioned.

The data were collected by documentation study, observation, and interview, Documentation study was carried out to find the data about the English teaching syllabus, including the materials of English subjects and the evaluation techniques used to measure the output. Observation was performed to obtain the data related to the activities carried out inside as well as outside the classroom. The classroom activities cover the techniques and procedures of English teaching and learning process. The activities outside the classroom are in the forms of extra-curricular activities and the physical as well as situational environments of the campus which are related to the English learning and acquisition efforts. Interview, moreover, was carried out as a complementary way to collect the data concerning a certain aspect which was considered obscure and incomplete. In this way, it is expected that the data collected were considered exhaustive and comprehensive. 
The analysis of the data mainly followed Miles and Huberman's suggestion of qualitative analysis in the forms of data reduction, data display, and conclusion or verification (Miles \& Huberman, 1972). Data reduction means that there were processes of selecting, organizing, abstracting, and simplifying (Miles \& Huberman, 1972). Then, the data were displayed to facilitate drawing conclusions. Finally, some conclusive points were made, discussed, and interpreted within the framework of language teaching and learning theories. This is to make the result of this study more systematic and meaningful.

\section{FINDINGS AND DISCUSSION}

Pondok Modern with its system of teaching English is likely to be what has been stated by that "coordinate system be developed in the students (Chastain, 1972). There are the strategy of applying English as daily language in Pondok Pesantren Modern Gontor .The second long term plan is expansion, development and maintenance of infrastructures and buildings in applying English as a daily language. The teaching guide says that each pattern is practiced and used in terms of hundreds and even thousands of utterances (Anonymous: 1984).

Grammar is not taught explicitly at this stage. It is largely learned through practice, i.e. that the grammatical patterns are directly applied through examples in contexts, and students are encouraged to draw their own structural generalizations by inference. In this way, "the study of grammar is kept at a functional level, being confined to those areas which were continually being used in speech (Rivers, 1977: 15). Grammar is taught at a later stage. It is taught in the target language with the use of English grammar terminologies.

In this lesson students are always stimulated to produce utterances as early as they have known new words and new patterns. By that way, it is expected that students really have acquired the basic stage of language. It has been generally acknowledged that language skills are cumulative, meaning that the real language proficiency is developed on the basis of skills built earlier. That is why, it appears to be easier to teach one who has known nothing than to teach one who seems to have had faulty mastery. (Strevens: 1978).

The evaluation is in terms of oral test as well as subjective written one in which students are to provide answers to questions and to make questions for the provided answers. Besides, they are also asked to correct erroneous sentences and to translate Indonesian sentences into English. The language deviating standard target language grammar usually uttered by younger students, to communicate among themselves, to show intimacy and informality, which noticeably existed when the writer became a student there. River's hypothesis seems to be theoretically irrefutable favoring this matter. Because students are plunged too soon into expressing themselves in the foreign language, they "tend to develop a glib but in accurate fluency, clothing native language structures in foreign vocabulary (Rivers).

A. The Strategy of Applying English as Daily Language in Pondok Pesantren Modern Gontor. According to the research that done by the researcher, there are four points that will be discussed in here, they are curriculum, the general strategy, teaching strategy and learning strategy.

\section{Curriculum}

The percentage of English is very different with Arabic language English is only about 20\% with all language programs in Gontor. The English materials for the students are: reading, 
grammar, composition and vocabularies. The time of the learning are: reading 2-3 hours of learning time, and grammar 1-2 hours of learning time.

The books is using by pondok is "Barlinge", a book produced by English person, and this book is not for the native speakers. The content of this book is about all parts of English with a proportional grammar and structure. This book is compatible with the students, but the problems are the book sometimes used a negative example, that is not common with the pondok situation, such as: a story about secular party, free live, etc.

\section{The General Strategy}

There are two general strategies in applying English as a daily language of Pondok Pesantern Modern Gontor in their learning activity.

a. Using continuing strategy (strategi berjenjang) to make an effective learning, we are using continuing strategy, if the students has ability from first class, will be easy to make the students learn about the material.

b. Make a language program in English week and Arabic week.

\section{Teaching strategy}

There are five teaching strategies that applied in pondok Pesantren Modern Gontor, they are Direct method, there are classes become the motivator and controller class in language learning Gontor manages an education system which trains teachers and students to apply Islamic brotherhood in their life. By this, they will understand and learn that egoism is blamed in the social life.there are some days to get some vocabularies and songs, giving different material in different level of class, there are controls in applying English as a daily language

\section{a. Direct Method}

In teaching there are using classical teaching in the classroom and out of the classroom. The strategy that used in here is direct method, it means what you see, you say. So, in teaching there is no translation.the teaching strategy in the class there is used direct method.

b. There are become the motivator and controller class in language learning that for the Fifth class became language learning motivator and the Sixth class do the control about student language activity, although there are not all the members of sixth class is a teacher. And the teacher or ustadz must be responsible about the learning activity in pondok.

c. There are some days to get some vocabularies and songs.

He also said that In Pondok also applied that Every Tuesday and Friday after pray Subuh and taking exercise, the students get the English from English song, this is daily activity. After that the students discuss some words or sentences of that song. That does not mean that students' communicative language is ungrammatical. In spite of the existence of some defects that need special attention here and there, their utterances are, generally speaking, intelligible because grammar which means "a proper way a language is used (Harsh, 1975: 3) has actually been included in and taught through contexts, as explained previously. Only does the grammar talked about in this chapter have the connotation of being a body of science consisting of piles of terminology about the elements from which language is systematically set up. 
The materials mostly consist of terminologies with their definitions and examples. Examining them closely, we will suspect that those materials are influenced by traditional grammar, among of which characteristics is "the inconsistency of defining parts of speech (Harsh, 1975: 3).

d. Giving different material in different level of class.

There are differentiate between old students and new students in applying English as a daily language. For the new students, sometimes get more material about basic English language, and there is different punishment between old and new students, for old students get more punishment than new students.

There are controls in applying English as a daily language.

e. The secretary of CLI said there are structures in language learning activity in Darul Makrifat, they are:

1) LAC (language advisory council), this is the place for the teacher/ustadz, the function are to control teaching activity and give punishment to students who break the rule.

2) CLI (central language improvement), this is the place for the students from 5 or 6 class, the function are for helping the students under them.

3) Rayon, In every rayon there are language mastery. The rayon is the place for the students from slept, study, and the other activity. In that place they must be use the English and Arabic language.

LAC gives CLI English language material and CLI gives it to the Rayon. Than the material that given by CLI gives to the students by Rayon. LAC controls these activities if there is any problem .Vocabularies learning is one word one day after pray Shubuh in Tuesday and Wednesday, teacher is the language leader in rayon .For all parts of pondok must be using Arabic and English language, if do not use it, there is no tolerance. There are hard punishments to students who break the language rule. But for new students in first half semester can be use Arabic language and a little English language, but in the last year they must use both language.

There are students language control, they are:

1) Language center

2) Management - teacher (LAC) - CLI (students) - rayon

3) There is spy in the center of students (usually from CLI), if there are students do a mistake, they will get punishment and the managerial order them to find the other students who do a mistake

He also said that the language teaching also done using three ways, they are:

1. Classroom activity

It means that the student gets the material from the teacher inside the class and then the student should be apply it in the daily live both inside and outside class.

2. Vocabularies everyday

It means the teacher gives some English vocabularies for the student every day in English week.Bio laboratory, language laboratory, English course or from magazine

3. Bio laboratory means all places in Pondok that to be place in applying English as a daily language such as in Rayon, in mosque, in class etc. the student not only apply English in bio laboratory and study the English in the class, but they also able to study English in language laboratory and from English course or from magazine.

4. Learning strategy 
In learning, there are also two strategies, they are Giving the job for the student, Give the vocabulary and practice it in any time and any place.

a. Giving the job for the student.

b. Give the vocabulary and practice it in any time and any place.

\section{CONCLUSION AND SUGGESTION}

Educational institutions deal with the process of producing alumni capable in certain aspect he or she focuses such as health, technology etc. and then he or she is hoped to be good and useful for his or her ummah. The word good and useful is value and can only be attained by the process which deals with values. In order to make gontor do not far away with science.There are many characteristic in their teaching - learning activity, but the primary method is direct method, what they know they say, this is one of their character. Every day Gontor's teacher always give their students one vocabularies to remember by the students, and if there are students break the rule about language, the management will punish them with an educational punishment, such as: arranging sentence, remembering words, take conversation, etc. the pondok management do not use a physical punishment.

In Gontor there are two organizations that manage about the language, there are CLI and LAC. CLI is the place for fifth students to control the students' language activity under them. And LAC is the place for the teacher to compose about English material and give punishment to students who break the language law.

The general strategy of pondok in applying English as a daily language are: Using continuing strategy (strategi berjenjang) and make a language program in English week an Arabic week. And the teaching strategies applied in Pondok, they are:

1. Direct Method

2. There are become the motivator and controller class in language learning

3. There are some days to get some vocabularies and songs.

4. Giving different material in different level of class.

5. There are controls in applying English as a daily language.

There are also some learning strategies, they are giving the job for the student and giving the vocabulary and practice it in any time and any place.

\section{REFERENCES}

Ary, Donald et.al. (1975). An Introduction to Research in Education. 2nd. Ed. Holt, Rinehart, and Winston. Inc.

Bahroni, Imam. (2012). Protected Economic Enterprises: an experience of Gontor System on Waqf Enlargement, paper presented at First International Conference on Waqf, Awqaf as Key Factor in the Advancement of Higher Education: Gontor-IIUM Experiences, at the Main Campus of ISID, Ponorogo.

Best, John W. (1959). Research In Education (Fourth edition), New Jersey: Prentice - Hall inc.

Bialystok, Ellen. (1990). Communication Strategies: A Psychological Analysis of Second Language Use. USA: Basil Blackwell. Inc.

Bogdan, Robert C. et al. (1992). Qualitative research for Education: an Introduction to Theory and Methods. USA: Allyn and Bacon. 
Brown, H. Douglas. (1987). Principles of Language Learning and Teaching. 2nd edition. New Jersey: Englewood Cliffs Prentice Hall Regents.

Byrne, Donn. (1985). English Teaching Perspectives. England: Longman.

Dryden, Gordon. Vos, Jannette. (2001). Revolusi Cara Belajar. Terj. Ahmad Baiquni. Bandung: Kaifa,.

Harmer, Jeremy. (1991). The Practice of English Language Teaching. London: Longman.

Hasan Ruqaiya. Martin, J.R. (1989). Language Development: Learning Language, Learning Culture. New Jersey: Ablex Publishing Corporation.

Mariyat, Akrim. (2012). Developing Endowment through Units of Economy outside the Campus: the experience of Pondok Modern Darussalam Gontor, Ponorogo, paper presented at First International Conference on Waqf, Awqaf as Key Factor in the Advancement of Higher Education: Gontor-IIUM Experiences, at the Main Campus of ISID, Ponorogo.

McDonough, Steven H. (1981). Psychology In Foreign Language Teaching. London: George \& Unwin.

Moleong, Lexy J. (1993). Metode Penelitian Kualitatif. Bandung: PT Remaja Rosda Karya.

Nunan, David. (1992). Research Methods in Language Learning. USA: Cambridge University Press.

Prabhu, N.S. (1987). Second Language Pedagogy. Oxford: Oxford University Press.

Serba Serbi Serba Singkat Tentang Pondok Pondok Modern Darussalam Gontor, 5th edition. (1997). Ponorogo: Darussalam Press.

Suharto, H. Ahmad \& Staf Sekretaris (compiler). (2011). Pimpinan Pondok, Profil Pondok Modern Darussalam Gontor. Ponorogo: Darussalam Press.

Wenden, Anita. Rubin, Oan. (1991). Learner Strategies in Language Learning. New Jersey: Pentice / Hall International.

Yule, George. (1985). The Study of Language: An Introduction. Cambridge: Cambridge University Press.

Zarkasyi, KH. Abdullah Syukri. (2005). Manajemen Pesantren: Pengalaman Pondok Modern Gontor, 2nd edition, Ponorogo: Trimurti Press.

Zarkasyi, Dr. Amal Fathullah, et. al. (2011). Profil Insititut Studi Islam Darussalam, 2nd edition, Ponorogo: Darussalam University Press.

Zarakasy, Hamid Fahmy, (2012). Education System Under Waqf Foundation (Case study of Modern Pondok Darussalam Gontor), paper presented at First International Conference on Waqf, Awqaf as Key Factor in the Advancement of Higher Education: Gontor-IIUM Experiences, at the Main Campus of ISID, Ponorogo. 